\title{
Asumisen sietämätön epävarmuus
}

\section{Mika Hyötyläinen}

Yhdyskuntasuunnittelu-lehden sivuilla keskusteltiin vuoden 2020 aikana kiitettävästi asumisesta ja asuntopolitiikasta. Keskustelun teemoja voisi niputtaa yhteen sanoilla asumiseen liittyvät epävarmuudet.

Ranta (2020) Osallistui keskusteluun pienten asuntojen rakentamista käsittelevällä katsauksella. Ranta muistutti, että pienten asuntojen suuresta kysynnästä huolimatta juuri nykyiseen markkinatilanteeseen yksipuolisesti vastaavan asuntokannan valtava kasvattaminen voi sisältää epävarmuustekijöitä. Teksti antoi aihetta pohtia, näemmekö esimerkiksi pienten asuntojen keskittymien myötä asumiskokemuksiin liittyviä ongelmia, kasvavaa eriytymiskehitystä tai asuinrakennusten ennenaikaista ja tuhlailevaa purkamista? Jääskeläinen (2020) puolestaan tarttui asuntorakentamisen toiseen kuumaan perunaan, täydennysrakentamiseen. Vaikka täydentämisen tavoitteet on usein ilmaistu houkuttelevina ja lupaavina, tietää Jääskeläinen kuitenkin, etteivät asukkaat aina innostu oman kaupunginosansa muutoskaavailuista. Jo korttelin kokoiset muutokset asuinympäristössä aiheuttavat helposti epävarmuutta ja huolestuneisuutta.

Kuopan ja kumppanien (2020) artikkeli kiinnitti huomiomme asumistilojen puutteisiin asumiskokemuksia sävyttävinä epäkohtina. Kun asumistilat eivät vastaa tarpeisiin, asukkaan suhde asuntoon heikkenee. Huonosti toimivat, pimeät ja ahtaat tilat, hissien puute ja muut esteettömyystekijät aiheuttivat vaikeuksia ja epävarmuutta artikkelissa haastateltujen asukkaiden arjessa. Verma (2020) puolestaan tutki vanhusten tarpeita asuinympäristöille ja pohti, kuinka ympäristöjä tulisi kehittää, jotta edellytykset hyvälle elämälle ja osallisuudelle säilyvät myös väestön ikääntyessä. Verman haastattelemien vanhusten toiveissa korostuivat pysyvyys ja normaali elämä tutussa ympäristössä.

Mainittakoon vielä Sutelan ja tovereiden (2020) tärkeä artikkeli kohtuuhintaisen asumisen määrittelystä. Kohtuuhintaisuuden käsitteen tulkinnanvaraisuus aiheuttaa helposti väärinymmärryksiä ja epävarmuutta sekä vaikeuttaa 
keskustelua asuntopolitiikan tavoitteista ja keinoista. Kirjoittajat totesivat asuntopolitiikkamme olevan kohtuuhintaisuuden näkökulmasta hajautunutta. Kun toimijoiden jakama käsite on määritelmältään puutteellinen ja termistö laajemminkin epäselvää, kärsivät asuntopolitiikan kokonaisuuden hahmottaminen ja sen myötä sen hallinta.

Asumiskokemuksiin ja asumisen käytäntöihin sekä asuntopolitiikkaan liittyviä lukuisia epävarmuuksia on tarkasteltu myös kansainvälisessä tutkimuskirjallisuudessa. Siellä aiheesta keskusteltaessa näkyy käytettävän yhä useammin nimitystä asumisprekaarius. Reilu vuosikymmen sitten sosiaalitieteissä tutkimusteemaksi nousi työn kasvava epävarmuus tai prekaarius. Talouden globaalit muutokset olivat synnyttäneet pätkätöistä, työttömyydestä ja tulojen epävarmuudesta kärsivän luokan, prekariaatin (standing, 2014), jota edustivat sekä työläiset että korkeakoulutetut. Sittemmin tutkimukset ovat osoittaneet prekariaatin kohtaavan taloudellisia ongelmia ja urakehityksen hidastumista, jotka heijastuvat esimerkiksi masennuksena ja toivottua myöhäisempänä perheenperustamisikänä.

Asumisen on nyt huomattu aiheuttavan vastaavia ongelmia, jotka korostuvat kaupungistumisen aikana. Prekaaristi asuvasta kotitaloudesta puhutaan, kun asunto on huonolaatuinen, ahdas, kallis tai ei muuten täytä joitakin kotitalouden perustarpeista (Pendall ym., 2012). Asumisprekaariudella viitataan myös ei toivottujen muuttojen aiheuttamaan ennustettavuuden puutteeseen omassa elämässä (colic-Peisker ym., 2015). Tutkimuksissa käytetäänkin usein ontologisen turvallisuuden käsitettä (Giddens, 1991) jolla viitataan juuri perusturvallisuuden tunteeseen ja oman elämän ennustettavuuteen. Davey (2020) huomauttaa, että asunnon menettämisen pelko on nykyään monille yksi asumiseen liittyvistä peruskokemuksista. Liittyivät pelot sitten lainanmaksukyvyn heikkenemiseen, asuntojen vuokrien nousuun, asuntojen purkamiseen tai ympäristön muutoksiin, pitkään jatkuvana pienikin pelko nakertaa ontologista turvallisuutta ja voimistaa asumisprekaariutta.

Toissa vuonna julkaistiin asumisprekaariuteen liittyvän kansainvälisen vertailututkimuksen tuloksia (Clair ym., 2019). Tutkimuksen mukaan yli puolet eurooppalaisista oli kokenut asumisprekaariutta. Pohjoismaissa sitä koettiin vähiten, Suomessa kuitenkin muita Pohjoismaita enemmän. Kotitalouksien tuloja nopeammin kasvavat asuntojen hinnat ja vuokrat varsinkin kaupungeissa ovat johtaneet siihen, että kallis asuminen on nykyään sekä pieni- että keskituloisten ongelma. Keskituloisissa kotitalouksissa asuminen on kasvanein menoerä 2008 finanssikriisin jälkeen kaikissa OECD-maissa (sutela ym., 2020). Työttömillä ja pienituloisilla sekä prekariaatilla on kuitenkin havaittu erityisiä asumisen epävarmuuden ja väliaikaisuuden hallintaan liittyviä ongelmia. 
Esimerkiksi Bentley ja kumppanit (2019) ovat tutkineet asumiseen ja työhön liittyvän 'kaksoisprekaariuden' haittavaikutuksia mielenterveydelle.

Asumisprekaariutta ilmenee myös eri ikäisillä ihmisillä. Kuten Verma (2020), myös Bates ym. (2019; 2020) tutkivat ikääntyvien ihmisten asumiskokemuksia. Yhteisön ja kotiseudun merkityksen havaittiin voimistuvan ikääntyvillä ja ympäristön muutosten aiheuttavan epävarmuutta. Asumisprekaarius voimistaa iän myötä tulevia haasteita, omaan terveyteen ja talouteen liittyviä huolia, ja heikentää mahdollisuuksia laadukkaaseen vanhenemiseen. (Bates ym., 2019; 2020.) Myös nuoret kokevat usein erityistä epävarmuutta asumisestaan. Varsinkin yksityisellä vuokra-asuntosektorilla vallitsevat sijoittajan vuokramarkkinat ja nuoret kaupunkilaiset asuvat ahtaasti ja maksavat tuloihinsa nähden vuokrissa suuria summia. Nuoruuden asumiseen liittyvät epävarmuudet heikentävät myöhemmän asumisuran kehitystä (Clapham ym., 2014).

Monet tutkijat pitävätkin yksityisessä vuokra-asunnossa asumista niin kauttaaltaan epävarmana, että se on yksi asumisprekaariuden määritelmistä (esim. Beer ym., 2016). Asumisprekaariutta koetaan silti asuntojen hallintamuodoista riippumatta. Omistusasujilla kokemuksissa voimistuvat sosiaalisesti hyväksytyn yksilön vastuun tuomat asumiseen liittyvät epävarmuudet. Vaikkapa lainanlyhennysongelmat tai asunnon arvon lasku nähdään herkästi yksilön epäonnistumisina taloudessaan ja sijoituksissaan, eikä niinkään rakenteellisten epäkohtien tuloksena (Balmer \& Bernet, 2015).

Suomi loistaa OECD:n tilastojen kärjessä alhaisilla asunnottomuusluvuillaan. Tiedämme, ettei asumisessa ole kuitenkaan kyse vain katosta pään päällä. Asuntokysymykseen vastaamisessa asunnottomuuden poistaminen on vasta tärkeä ensimmäinen askel. Asuntokysymyksen moniulotteisuus on hiljalleen nousemassa tutkimuskohteeksi ja julkiseen keskusteluun. Asumisprekaariudella on käsitteenä potentiaalia asuntokysymyksen ymmärtämisessä. Se kokoaa yhteen asumiseen liittyviä monisyisiä epävarmuuksia ja ongelmia. Se toimii kattokäsitteenä kuvaamaan, kuinka asumista, yhtä tärkeimmistä perustarpeistamme, ja siihen liittyviä kokemuksia, sävyttää monille jatkuva, eri asteisena ilmenevä epävarmuus. Asumiskysymys tulisi meilläkin ymmärtää yhä enemmän kysymyksenä siitä, kuinka takaamme, että ihmisillä on varmuuden ja ennustettavuuden kokemus asumisestaan ja asuinympäristöstään. Tämän auttaisi ajankohtaisessa asuntopolitiikan kehittämistyössä ja asumisen ja asumisympäristöjen suunnittelussa ja laadun parantamisessa.

KIRJALLISUUS

Balmer, I. \& Bernet, T. (2015). Housing as a common resource? Decommodification and self-organization in housing: Examples from Germany and Switzerland. 
Bates, L., Wiles, J., Kearns, R. \& Coleman, T. (2019). Precariously placed: Home, housing and wellbeing for older renters. Health \& Place, 58, 102-152.

Bates, L., Kearns, R., Coleman, T. \& Wiles, J. (2020). 'You can't put your roots down': housing pathways, rental tenure and precarity in older age. Housing Studies, 35(8), 1442-1467.

Beer, A., Bentley, R., Baker, E., Mason, K., Mallett, S., Kavanagh, A. \& LaMontagne, T. (2016). Neoliberalism, economic restructuring and policy change: Precarious housing and precarious employment in Australia. Urban studies, 53(8), 1542-1558.

Bentley, R., Baker, E. \& Aitken, Z. (2019). The 'double precarity'of employment insecurity and unaffordable housing and its impact on mental health. Social Science \& Medicine, 225, 9-16.

Clair, A., Reeves, A., McKee, M. \& Stuckler, D. (2019). Constructing a housing precariousness measure for Europe. Journal of European Social Policy, 29(1), 13-28.

Clapham, D., Mackie, P., Orford, S., Thomas, I. \& Buckley, K. (2014). The housing pathways of young people in the UK. Environment and Planning A, 46(8), 2016-2031.

Colic-Peisker, V., Ong, R. \& Wood, G. (2015). Asset poverty, precarious housing and ontological security in older age: an Australian case study. International Journal of Housing Policy, 15(2), 167-186.

Davey, R. (2020). Snakes and ladders: legal coercion, housing precarity, and home making aspirations in southern England. Journal of the Royal Anthropological Institute, 26(1), 12-29.

Giddens, A. (1991). Modernity and self-identity: Self and society in the late modern age. Cambridge: Polity.

Jääskeläinen, L. (2020). Tiivistyvän kaupunkirakentamisen oikeudellisista reunaehdoista. Yhdyskuntasuun nittelu, 58(1), 70-78.

Kuoppa, J., Saarimaa, S., Ruoppila, S., Laine, M., Nieminen, N. \& Haverinen, R. (2020). Houkuttelevan asumisen ainekset. Yhdyskuntasuunnittelu, 58(2), 10-32.

Pendall, R., Theodos, B., \& Hildner, K. (2016). Why high-poverty neighborhoods persist: The role of precarious housing. Urban Affairs Review, 52(1), 33-65

Ranta, E. (2020). Pienet asunnot Vantaalla. Yhdyskuntasuunnittelu, 58(1), 50-54.

Standing, G. (2014). The Precariat - The new dangerous class. Amalgam, 6(6-7), 115-119.

Sutela, E., Ruoppila, S., Rasinkangas, J. \& Juvenius, J. (2020). Kohtuuhintaisen asumisen hajanainen kokonai suus. Yhdyskuntasuunnittelu, 58(1), 10-32.

Verma, I. (2020). Asuinalueiden kehittäminen ikääntyvälle väestölle. Yhdyskuntasuunnittelu, 58(1), 33-49. 